This is a draft chapter / article. The final version is available in Research Handbook on Boards of Directors edited by [J onas Gabrielsson, Professor, Halmstad University, Sweden, Sibel Yamak, University of Wolverhampton, UK and Wafa Khlif, Toulouse Business School, Spain], published in 2019, Edward Elgar Publishing Ltd https://www.e-elgar.com/shop/research-handbook-on-boards-of-directors 


\author{
Research Handbook on Boards of Directors \\ Jonas Gabrielsson, Sibel Yamak and Wafa Khlif (eds) \\ Edward Elgar
}

https://www.e-elgar.com/shop/research-handbook-on-boards-of-directors

CORPORATE GOVERNANCE AND CLIMATE CHANGE:

THE NEW ZEITGEIST OF SUSTAINABILITY FOR BOARDS OF DIRECTORS

\title{
Thomas Clarke
}

\section{Introduction}

Corporate governance essentially has three elements defining corporate purpose, balancing interests, and measuring performance. Historically these elements have been broadly interpreted with corporate purpose related to the wide interests of stakeholders and the community amounting to a licence to operate. The governance mechanisms have been understood as providing a sense of accountability, responsibility and fairness regarding the interests of the different participants in the company. Finally, performance measurement also has been widely conceived as contributing value in financial, social and environmental terms. This careful historical calibration of interests was deliberately overturned by the doctrine of shareholder value and imposition of the idea of shareholder primacy. We are now entering an era in which the irresponsibility of such narrow estimations of corporate purpose, governance and performance is becoming manifest. The onset of significant, damaging and apparently relentless human and industry induced climate change has demanded a reconceptualization of the business licence to operate around the principles of sustainability (Klein 2015; Rasche and Waddock 2014).

This chapter highlights the contrast between the deceptive conduct of greenwashing that sadly typified much of the past corporate response to the challenge of environmental and social responsibility, and the transformation in the thinking and action of business in recent years as the reality of climate change has become more apparent. It is becoming realized that climate change represents as great a threat to business continuity and 
survival, as it does to the survival of the environment. This reconceptualization of corporate social and environmental responsibility demands the exercise of a new Zeitung of integrated governance where climate risks are fully recognized, and the necessary strategies and risk management are introduced, guided by appropriate measures and targets (Figure 1).

\title{
Figure 1 Integration of Governance Purpose and Performance
}

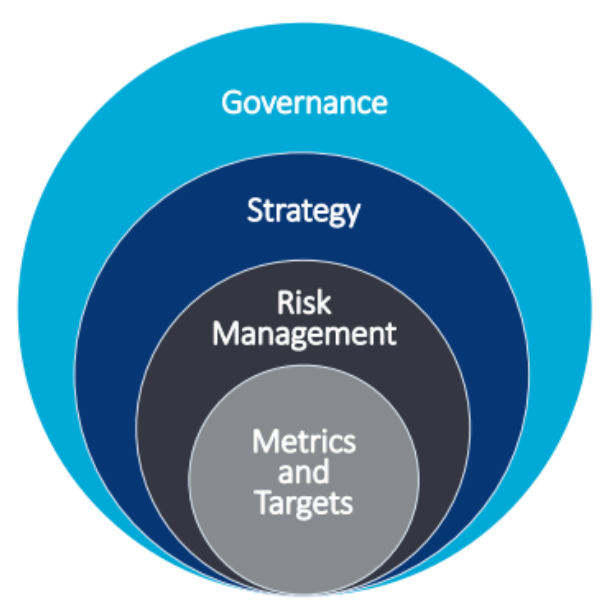

\author{
Governance \\ The organization's governance around climate-related risks and \\ opportunities \\ Strategy \\ The actual and potential impacts of climate-related risks and \\ opportunities on the organization's businesses, strategy, and \\ financial planning \\ Risk Management \\ The processes used by the organization to identify, assess, and \\ manage climate-related risks \\ Metrics and Targets \\ The metrics and targets used to assess and manage relevant \\ climate-related risks and opportunities
}

Source: Adapted from TCFD (2017)

\section{The Compound Failures of Greenwashing}

While corporate social and environmental responsibility (CSR) reporting has moved over the decades from the margins to the mainstream of business reporting, it is hard not to escape the conclusion that this is largely symbolic rather than substantive CSR - that is, it does not changing business models, simply it represents a change in rhetoric (Crane et al 2014; Bannerjee 2012). Corporations have come to realise they must be seen to be socially and environmentally responsible, and, in many cases, the boards and directors of these 
companies wish to be as responsible as possible, within the limits of achieving their financial targets. Arnaud Sales (2019) records the profound process of institutionalization of corporate social responsibility that has occurred in recent years: "A veritable arsenal of processes, rules and measures deployed by a sizeable number of experts, accredited specialists and associates of a large number of organizations is involved in implementing CSR." In this context, while limited action is deemed acceptable, the transformation of business models, strategies and practices is often conceived to be too difficult or too premature without a fundamental shift in the market, that is when all competitors in an industry determine that change is either necessary or unavoidable. Vogel (2005) identified, CSR as interpreted by corporations within the logic of existing market constraints, and there is rarely the perception by corporations themselves that it is possible to change markets, and transform technologies. Market leaders rarely take the lead by adopting radically different standards of social and environmental responsibility on their own.

As Bowen explains: "Symbolic corporate environmentalism consists of shared meanings and representations around changes made by managers that they describe as primarily for environmental reasons... However, some of these symbols are completely disconnected from the impacts that firms have on the natural environment, and many more have less substantive environmental impact than they symbolically promise. Despite apparently widespread corporate environmentalism, industrial activities are pushing society closer to and, in some cases, exceeding planetary boundaries. The gap between firm's symbolic activities and the reality of environmental damage endangers our natural surroundings and, ultimately, may threaten the stability of current economic and social systems" (2014:13).

Alhough there is now a widespread corporate acceptance of the concepts of corporate social and environmental responsibility, CSR continues to invite a degree of scepticism, most seriously for engaging in amoral apologetics for unacceptable corporate behavior, and the apparent capacity of corporations, particularly in the resources sector, to express 
CSR ideals while engaging in every opportunity to make money regardless of the environmental or social consequences (Wright and Nyberg 2015). CSR has matured over recent decades, driven by evolving global guidelines, national regulation, increased stakeholder expectations and more demanding corporate disclosure requirements, together with widespread voluntary initiatives by corporations to embed CSR into their core business. Yet what is presently happening lacks the speed and scale to bring about the systemic change required to remedy increasing social and environmental challenges, Jane Nelson argues:

“...The negative headlines persist, fuelled by reports of sweat-shops in low-income countries producing cheap goods for OECD markets, fatal tragedies such as the collapse of the Rana Plaza garment factory in Bangladesh in 2013 and the Turkish mining disaster in 2014, and catastrophic environmental accidents. Moreover, the legacy of the global financial crisis, concerns about corporate tax practices and challenges such as youth unemployment and climate change have forced corporations to lift their sights further above the bottom line and to judge their performance against wider social goals.

Economic growth must now be more inclusive and more sustainable. The onus is on firms to produce more jobs, products, services and infrastructure for more people, while putting more emphasis on decent work and fairness, and less strain on natural resources" (Nelson 2014)

In the face of increasing public demands for greater responsibility companies have complied minimally with standards. Reuter and Ueberbacher (2019) provide an inventory of 'strategies to avert social responsibility'. They differentiate proactive type tactics aimed at avoiding controversies - and reactive type tactics - designed to contain social responsibility issues that arise. They then differentiate symbolic tactics and substantive tactics. They set out and systematically identify four types of strategies (i.e., concealment, manipulation, denial and discrediting) to defend social irresponsibility and despite everything succeed. Rather than in any way alleviating environmental and social problems 
the practice of greenwashing has served to compound immeasurably the problems by diverting attention from effective solutions.

From the origins of the business and environment movement in the early 1990s, there has been a strong inclination within corporations to dissemble concerning environmental intentions and mislead regarding environmental achievements (Table 1). While promised genuine commitments to environmental responsibility by corporations, communities around the world too often have instead confronted a tsunami tide of greenwash (Greenpeace 1992; 2012; Gillespie 2008; Lyon and Maxwell 2011; Walker and Wan 2012).

\section{Table 1 Definitions of Greenwashing}

Disinformation disseminated by an organisation so as to present an environmentally public image (OED 2012)

Advertising or marketing that misleads the public by stressing the supposed environmental credentials of a person, company or product when these are unsubstantiated or irrelevant (Gillespie 2008)

The act of misleading consumers regarding the environmental practices of a company (firm level greenwashing) or environmental benefits of a product or service (product level greenwashing) (TerraChoice 2007)

A strategy that companies adopt to engage in symbolic communication of environmental issues without substantially addressing them in action (Walker and Wan 2012)

The selective disclosure of positive information about a company's environmental or social performance, without full disclosure of negative information on these dimensions, so as to create an overly positive corporate image (Lyon and Maxwell 2011).

The disclosure of one element of a corporations environmental performance, for example a commitment to zero emissions, and withdrawing from this commitment when the mismatch is exposed between the proactive-sounding statements and less favourable ongoing environmental impacts (Bowen 2014:2).

Source: Adapted from Bowen (2014:21) 
Greenwashing can be found in the policies and practices of many corporations regarding their supply chains, manufacturing, and operations, both consciously and unconsciously presenting a distorted view of the real commitments of companies towards social and environmental responsibility. However it is in retail marketing the greenwashing movement has often proved at its most pernicious. While the general public is expressing deeper concerns about the importance of environmental and social responsibility, corporations marketing campaigns have often responded with a degree of cynicism in the association of products with environmental integrity, obligation and good health, when this is at best fatuous (Table 2).

\section{Table 2 Common Corporate Product Greenwashing Strategies}

\section{Hidden Trade-offs}

The suggestion a product is "green" based on an unreasonably narrow set of attributes without attention to other important environmental issues. Paper, for example, is not necessarily environmentally preferable just because it comes from a sustainably harvested forest. Other important environmental issues in the paper-making process, including energy, greenhouse gas emissions, and water and air pollution, may be equally or more significant.

\section{No Proof Offered}

An environmental claim that cannot be substantiated by readily accessible supporting information, or by reliable third-party certification. Common examples include paper and tissue products that claim various percentages of post-consumer recycled content without providing any evidence.

\section{Deliberate Vagueness}

Claims that are poorly defined or so broad that their real meaning is likely to be misunderstood by the consumer. "All-natural" is an example. Arsenic, uranium, mercury, and formaldehyde are all naturally occurring, and poisonous. "All natural" isn't necessarily "green".

\section{Irrelevant Detail}

Environmental claims that may be truthful but are unimportant or unhelpful for consumers seeking environmentally sound products. "CFC-free" is a common example, since it is a frequent claim despite the fact that CFCs are banned by law. 


\section{Deliberate Distraction}

Claims that may be true in themselves about the product category, but that risk distracting the consumer from the greater environmental impacts of the category as a whole. Organic cigarettes might be an example of this category, as might be fuel-efficient sport-utility vehicles.

\section{Deliberate Deception}

Environmental claims that are simply false or wildly exaggerated. The most common examples include products falsely claiming to be Energy Star certified or registered.

\section{False Labelling}

Products that, through either words or images on product labels are intended to mislead, for example contain images of health irrelevant to the product, or give the impression of third-party endorsement where no such endorsement actually exists.

(Source: Adapted from TerraChoice (2010:10)

Greenwashing can be the public face of a more serious neglect of environmental planning and risk management in core business strategies. As the complexity and scale of corporate operations internationally increases, even as the regulatory framework becomes more developed, the imminent risk of environmental disaster is compounded. This can result in corporations being responsible for catastrophic environmental disasters, the consequences of which they cannot escape. Corporations are beginning to learn that greenwashing can come at a terrible cost as recent corporate environmental catastrophes amply illustrate.

There are recent cases of major corporations that have encountered the environmental risks which can implode with immense unforeseen costs. For example, the British oil company BP successfully projected itself for two decades internationally as the best managed oil corporation in the world. It painted its petrol pumps green, and referred to its BP logo as 'beyond petroleum,' suggesting it was the most environmentally responsible oil corporation. This all changed after BP was involved in one of the worst man-made environmental disasters when its Deepwater Horizon oil rig exploded in the Gulf of Mexico on 20 April 2010. After five years of litigation on 5 February 2015 BP agreed a \$20.8 billion civil claims settlement with US federal and state authorities over the 2010 Deepwater Horizon disaster, with $\$ 8.1$ billion of the funds designated for coastal wetlands 
and marine mammals as part of a 15 year Gulf of Mexico restoration program. The goals of reviving the Gulf Coast focus on wildlife, habitat, water quality and recreational activities. The deal was the largest ever reached by the Department of Justice against a single entity. BP will not be allowed to take any tax deductions for the civil portion of its penalty and if the company changes ownership the US can demand immediate payment from BP. BP already has paid out $\$ 5.8$ billion to people and businesses hurt by the oil spill as part of a 2012 settlement, and the company faced damages claims connected to class action settlements and law suits brought in addition to the earlier settlements. The company also faced securities litigation brought on behalf of some investors (Financial Times 6 October 2015).

The US Attorney General, Loretta Lynch said "BP is receiving the punishment it deserves, while also providing critical compensation for the injuries it caused to the environment and the economy of the Gulf region. The steep penalty should inspire BP and its peers to take every measure necessary to ensure that nothing like this can ever happen again." The spill “inflicted unprecedented damage”, said Lynch. "Ecosystems were disrupted.

Businesses were shuttered. Countless men and women lost their livelihoods and their sense of security" (The Guardian 6 October 2015). The settlement took BP's total budget for the oil spill to more than $\$ 54$ billion with 18 years to pay the fine. BP lost 55\% of its share price in the months after the oil spill, and five years later still had not recovered it's earlier market capitalisation, as it proceeded through a major divestiture of assets in the ensuing years. This was the largest offshore oil spill in US history, and was regarded as one of the worst illustrations of corporate irresponsibility to occur anywhere in the world. Yet this tragic disaster that cost the lives of 11 oil rig workers could have been prevented as the Report to the President prepared by the National Commission on Deepwater insisted (National Commission 2011). Another investigation, the Report of the Ocean Energy Management, Regulation and Enforcement into the rig explosion found that BP, and in some instances contractors, failed to follow a series of federal safety regulations (2011). A third study by Berkeley University concluded "This disaster was preventable had existing progressive guidelines and practices been followed. This catastrophic failure 
appears to have resulted from multiple violations of the laws of public resource development, and its proper regulatory oversight... These failures (to contain, control, mitigate, plan, and clean-up) appear to be deeply rooted in a multi-decade history of organizational malfunction and short-sightedness" (Deepwater Horizon Study Group 2011:5).

In fact, BP had a scarcely concealed a long history of appalling health and safety records that stretched back through a 2005 explosion at its Texas City Oil Refinery which caused 15 deaths and injured 180 people; the largest oil spill on Alaska's North Slope; two further toxic spills from the Texas City refinery in 2007 and 2010; and a Caspian Sea gas leak and blow out in 2008. BP's dismal safety record was known in the industry, and BP refineries in Ohio and Texas accounted for $97 \%$ of the "egregious, wilful" violations recorded by the US Occupational Safety and Health and Administration (OSHA). These violations are determined when an employer demonstrates an "intentional disregard for the requirements of the law, or showed plain indifference to employee safety and health" (ABC News 27 May 2010). Ultimately this abysmal health and safety record was the responsibility of the BP Board, which had focused on cost cutting and profitability for too long, neglecting fundamentals that caused this disaster.

Another contemporary illustration of a respected international company confronting disaster because of its neglect and defiance towards essential environmental standards is the German car corporation Volkswagen. In September 2015 VW cars admitted illicitly installing software in 11 million car engines over several years that allowed the cars to pass regulators laboratory emissions tests, but belched out toxic nitrogen oxides when travelling normally on the road. As VW faced a litany of fines, lawsuits and recall costs, its reputation for engineering excellence and environmental responsibility was shredded and a subject of widespread ridicule. This flagrant abuse of environmental standards was ultimately a result of arrogance, lax board of director controls and a paternalist corporate governance culture described in Germany as "uniquely awful" (Financial Times 4 October 2015). 
After seeing the company lose over a third of its market capitalisation in a matter of days, the company announced it would set aside $\$ 7.3$ billion dollars, the equivalent of six months profits to cover the costs of making the cars comply with pollution standards. The car maker had become the most successful in Europe as the result of its 'clean diesel' advertising, and the diesel engines which were affected by the fraud accounted for half of sales. Too late, the outgoing CEO Martin Winterkorn announced a change of heart, and that the company would introduce 20 new hybrid or all-electric vehicles by the 2020 (New York Times 22 September 2015). Other European manufacturers announced plans for electric cars including Volvo, which committed to a fully electric fleet. The sense that things were changing was undermined by a discovery that experiments had been conducted with monkeys in the US inhaling diesel exhaust, and with humans in Germany to test the impact of inhaling nitrogen dioxide, by a consultancy hired by the car manufacturers Volkswagen, Daimler and BMW. The European Commission announced in 2018 it was intent on pursuing legal action in Germany and eight other countries regarding their chronic failure to enforce air quality standards claiming 400,000 people died prematurely in Europe each year as a result of air pollution (Ewing 2018).

Corporate disasters by companies formerly regarded as leaders in their sector are a salutary warning to other corporations to be alert to the very real hazards they will face in a more widespread and immediate way with the onset of climate change if they neglect their social and environmental duties. Though many international corporations are beginning to take seriously this threat, others are clinging to their traditional business models while they can still extract profit from them, particularly in the fossil fuel industries. To take one example, Shell continues as one of the largest oil corporations in the world and the most carbon intensive. The senior executives of Shell in the 1970s made their name with the use of 'scenario planning' to succesfully anticipate the oil crisis, however they seem to have signally failed in their planning for the far more dramatic consquences of climate change except to record fossil fuels as the major source of energy through to 2050 (Shell 2008). Shell's official view is that "fossil fuels will be a big part of 
the energy mix for decades to come... and would still even in 2050 supply over 60 per cent of global energy" (Brinded 2011).

As Greenpeace (2012) suggests what appears a prediction, becomes a self-fulfilling prophecy if the weight of the existing fossil fuel companies assets are utilised to continue to dominate energy markets and exclude or undercut competition from renewable energy. What Shell appears to be planning for is to continue to use as much fossil fuels for as long as possible. This would mean that energy related carbon dioxide emissions would not decline. Yet Shell accepts that climate change is one of the biggest challenges facing society and offered programs that help drivers to use less energy and emit fewer carbon dioxide emissions while it continues to develop more sources of oil and gas including the tar sands of Canada. In 2002, Shell's committee of managing directors considered that “essentially the Group's business was not to decarbonise but rather take advantage of opportunities which had arisen as a result of the world's desire to decarbonise." The committee argued "it was not unreasonable to expect that the Group could pursue decarbonisation as a good business case (Shell 2002)". Since then Shell has marginalised its interest in renewables to concentrate further on development of fossil fuels (Ten Kate 2011). This is not only environmentally disastrous, but ultimately could prove totally disastrous for Shell as a company.

It may be the case that scenario planning at Shell has been replaced by a dependence on stranded fossil fuel assets that amounts to a death wish. Meanwhile other corporations around the world are wrestling with the challenges brought by climate change and the insistent logic to reduce emissions which is becoming universal among governments, business and the community since the Paris Agreement of 2015.

\section{The Impact of Climate Change}

In his review on The Economics of Climate Change Sir Nicholas Stern (2006) called climate change "The greatest market failure the world has ever seen." He insisted the 
choice we faced was taking mitigation action now, or very expensive adaptation in the future, and concluded "There is still time to avoid the worst impacts of climate change, if we take strong action now" (Stern 2006). Stern insisted: "The scientific evidence that climate change is a serious and urgent issue is now compelling. It warrants strong action to reduce greenhouse gas emissions around the world to reduce the risk of very damaging and potentially irreversible impacts on ecosystems, societies and economies. With good policies the costs of action need not be prohibitive and would be much smaller than the damage averted" (Stern 2006: iv). Stern highlights how the effects of climate change are global, inter-temporal and highly inequitable. Climate change is a result of the externality associated with greenhouse-gas emissions entailing costs that are not paid for by those who create the emissions. Stern highlights a number of features of climate change that together distinguish it from other externalities:

- It is global in its causes and consequences;

- The impacts of climate change are long-term and persistent;

- Uncertainties and risks in the economic impacts are pervasive.

- There is a serious risk of major, irreversible change with non-marginal economic effects (Stern 2006:23).

The phenomenon of climate changes is gradually becoming part of the discourse of daily life. This is anthropogenic climate change - that is what we did to the earth's climate (and what consequences this will have). Climate change is according to the United Nations Framework Convention on Climate Change (UNFCCC): "A change of climate which is attributed directly or indirectly to human activity that alters the composition of the global atmosphere and which is in addition to natural climate variability observed over comparable time periods" (UNFCCC 2010; 2013; 2007). Climate change is caused by the increased emission of carbon dioxide and other greenhouse gases, which accumulate in the atmosphere and prevent heat radiating into space. The consequences of climate change range from a gradual to a catastrophic impact on the environment, ecology, economy and society. The Inter-governmental Panel on Climate Change (IPCC) was established by the 
World Meteorological Organization (WMO) and the United Nations Environment Programme (UNEP) in 1988, with the mandate to provide the world community with the most up-to-date and comprehensive scientific, technical, and socio-economic information about climate change. The IPCC assessments have played a major role in motivating governments to adopt and implement policies in responding to climate change, including the United Nations Framework Convention on Climate Change and the Kyoto Protocol (IPCC 2014).

The IPCC issued a risk assessment report on 31 March 2014 stating that the effects of climate change are already occurring on all continents and across the oceans. The world is unprepared for the imminent risks of a changing climate, and while there are opportunities to respond to such risks, the risks will be very difficult to manage with high levels of warming (IPCC 2014). The report suggests that though the nature of the risks of climate change are becoming increasingly clear, climate change will continue to produce unpleasant surprises. Vulnerable people, industries and ecosystems around the world are identified in the report. The report finds that risk from a changing climate is due to vulnerability (lack of preparedness), and exposure (people and assets in harm's way), overlapping with increasing hazards (the sudden triggering of climate events or trends. Intelligent intervention to decrease risk in each of these three dilemmas is possible. Vicente Barros, the Co-Chair of the group of scientists who produced the report commented: "We live in an era of man-made climate change. In many cases we are not prepared for the climate-related risks that we already face. Investments in better preparations can pay dividends both for the present and for the future...Part of the reason adaptation is so important is the world faces a host of risks from climate change already baked into the climate system, due to past emissions and existing infrastructure" (IPCC 2014:ix).

There is a growing consensus on climate change that what we have witnessed since the 1950s is without precedent in recent millennia: 
- In the Northern Hemisphere the last 30 years have been the warmest since AngloSaxon times, and eight of the ten warmest years on record in the UK have been since 2002 (Meteorological Office 2014);

- The atmospheric concentration of greenhouse gases are now at levels not seen in 800,000 years;

- The rate of sea level rise is now quicker than at any time over the last two millennia (IPCC 2014);

- Though natural fluctuations may mask the impact temporarily, the underlying human-induced warming trend of two-tenths of a degree per decade has continued since the 1970s (Otto 2015).

In response to these impending threats the 2010 UN Climate Change Conference in Cancun, Mexico agreed to reduce greenhouse gas emissions and to help developing nations to protect themselves from climate impacts, and to build their own sustainable futures. Under the Climate Change Convention they included a review for nations on their progress towards the agreed objective of keeping the average global temperature rise below two degrees Celsius (with an agreement to review this objective in future on the basis of further scientific knowledge). The explanation for the two degrees maximum increase, is that beyond this point climate change may become non-linear, that is unpredictable and compounding catastrophic weather events could occur (UNFCC 2010). Climate change refers to "a change in the state of the climate that can be identified (e.g., by using statistical tests) by changes in the mean and/or the variability of its properties, and that persists for an extended period, typically decades or longer" (IPCC 2014). The UNFCCC makes the significant distinction between climate change attributable to human activities altering the atmospheric composition, and climate variability attributable to natural causes (United Nations 1992). The IPCC (2014) report assesses the risks climate change poses for human and natural systems, and considers how these risks may be reduced or managed through adaptation and mitigation, examining options, constraints, resilience and limits of adaptation. This assessment is difficult since climate change involves complex interactions and changing likelihoods of many and diverse impacts. The 
focus on risk supports decision making in the context of climate change, and allows societies, government and business to perceive the degree of risk, and to consider modes of mitigation or adaptation, with reference to impacts, vulnerability and exposure.

There is significant evidence of serious impacts on natural and human systems on all continents and across all oceans, however the impact is strongest and most comprehensive for natural systems with changing precipitation levels affecting water resources, thawing permafrost, and many terrestrial, freshwater and marine species shifting their geographic range and migration patterns in response to climate change. People who are economically or socially marginalised are especially vulnerable to the impact of climate change. The widespread impact of recent climate-related extremes such as heat-waves, droughts, floods, cyclones and wildfires reveal vulnerability and exposure of both eco-systems and human systems to current climate variability (IPCC 2014:6). Governments throughout the world are already extensively engaged in developing adaptation policies for example in coastal and water management, environmental protection, land planning, protecting infrastructure and disaster management and reforestation. In these complex situations iterative risk management is required to deal with continuing uncertainty and constant monitoring of impacts (IPCC (2014:8).

The great weight of scientific evidence accumulated by successive reports of the IPCC, and a multitude of other scientific projects and policy reviews, brought recognition of the seriousness of the challenge facing humanity and the environment, and the need for deep cuts in global emissions. Yet a prolonged apparent incapacity to reach agreement followed on how this policy might be effectively and equitably implemented across the planet, as manifest in the limits of the 2009 Copenhagen Framework Convention on Climate Change (UNFCCC 2009; BBC 2009). Following extensive rounds of international negotiations over four years in preparation for the 21st Session of the Conference of the Parties to the United Nations FCCC (COP 21) in Paris in November 2015, at last seizing the opportunity to find a way forward, a total of 196 countries reached an historic moment in 
global diplomacy with a universal climate agreement more rigorous and ambitious than conceived possible earlier (UNFCCC 2015).

\section{Committing to the Paris Agreement}

The Paris agreement aims to substantially "strengthen the global response to the threat of climate change" while maintaining sustainable development and efforts to eradicate poverty UNFCCC 2015:22). Critically the agreement commits to more demanding long term mitigation efforts in Article 2(a): Committing to the Paris Agreement means "Holding the increase in the global average temperature to well be-low $2^{\circ} \mathrm{C}$ above preindustrial levels and to pursue efforts to limit the temperature increase to $1.5^{\circ} \mathrm{C}$ above preindustrial levels, recognizing that this would significantly reduce the risks and impacts of climate change" (UNFCCC 2015:22).

Reinforcing this commitment is the agreement to a robust transparency framework for emissions reductions with common accounting standards, national reporting, and independent expert review. The agreement establishes binding commitments of all parties to make "nationally determined contributions" (NDCs) and to pursue the necessary domestic emissions reductions measure to achieve these (CCES 2015). In addition to annual reporting, every five years countries are expected to develop new NDCs that represent a significant progression on previous targets. While it is possible that some countries may breach the caps on emissions, over time there is the possibility of negotiating to renew and increase emissions reductions.

The momentous diplomatic breakthrough achieved in the 2015 Paris Agreement, together with the substantial policy development and publications of the Stern Review, IPCC, and countless other international agencies, market intermediaries, business and civil society bodies, and national and legal authorities have helped to propel the business world into an 
urgent recognition of the dramatic consequences of unrestrained industrial activity upon the environment, and how little time there is to put this right.

What this scenario suggests is certainly not business as usual. The traditional conception of corporations profit maximising and leaving others to worry about the externalities they create simply does not work in a context of the impending consequences of climate change. In this context not only governments, but business and the wider community have to engage in the immediate and urgent stewardship and recovery of the environment. Business corporations will respond - or will be made to respond - by shareholders, stakeholders and governments to the demand that they act with greater responsibility in their use of resources and impact on the community and environment.

This is a paradigm shift as dramatic as any that has been applied to Thomas Kuhn's Structure of Scientific Revolutions. We have to "begin the extraordinary investigations that lead the profession at last to a new set of commitments, a new basis for the practice of science." Kuhn explains "The extraordinary episodes in which that shift of professional commitments occurs are the ones known ... as scientific revolutions. They are the tradition-shattering complements to the tradition-bound activity of normal science" (Kuhn 1970:7). This paradigm shift impelled by the real and imminent danger of climate change includes a fundamental widening and deepening of the traditional conception of professional directors' duties. This reconceiving of the responsibilities of directors is occurring in a context of institutional transformation (Lawrence and Suddaby 2006) in finance, law and regulation in which profound shifts are beginning to occur due to the impact of the recognition of the consequences of climate change.

The election of President Trump was a shock to the emerging global determination to resist climate change in his opposition to the Paris agreement, and support for coal and other fossil fuel industries. However, the weight of the U.S. Global Change Research Program Climate Science Special Report (CSSR 2017) stating that "evidence for a changing climate abounds, from the top of the atmosphere to the depths of the oceans" 
supported the conclusions of the IPCC (2014). Across America state governments, universities, and corporations confirmed they would continue to support action to meet the Paris Agreement. (We Are Still In 2017; Houser et al 2015).

Former Goldman Sachs CEO, and U.S. Treasurer Henry M. Paulson who had to negotiate and resolve the risk of the global financial crisis, is now co-Chair with Michael R. Blumberg of the Risky Business Project an environmental consultancy, and is helping others to get the message, "I know a lot about financial risks - in fact, I spent nearly my whole career managing risks and dealing with financial crisis. Today I see another type of crisis looming: A climate crisis. And while not financial in nature, it threatens our economy just the same" (Risky Business 2014:5). In response to conservative critics who emphasise the high price of early intervention, Paulson insists, "Our failure to act on the underlying problem is deeply misguided, financially and logically. In a future with more severe storms, longer fire seasons, and rising seas that imperil coastal cities, public funding to pay for adaptations or disaster relief will add significantly to our fiscal deficit and threaten our long-term economic security. A tax on carbon emissions will unleash a wave of innovation to develop technologies, lower the costs of clean energy and create jobs as we and other nations develop new energy products and infrastructure" (Paulson 2014).

At a global level the effort to address the risks to the planet caused by greenhouse gas emissions has continued with, for example, Michael Blumberg on behalf of the Financial Stability Board established by the G20, developing policy through the Task Force on Climate Related Financial Disclosure (TCFD). The TFCD stated in its first report, "The expected transition to a lower-carbon economy is estimated to require around $\$ 1$ trillion of investments a year for the foreseeable future, generating new investment opportunities. At the same time, the risk-return profile of organizations exposed to climate related risks may change significantly as such organizations may be more affected by physical impacts of climate change, climate policy, and new technologies. In fact, a 2015 study estimated the value at risk, as a result of climate change, to the total global stock of manageable assets 
as ranging from $\$ 4.2$ trillion to $\$ 43$ trillion between now and the end of the century" (TCFD 2017ii); IEA 2015; EIU 2015). The TCFD maintains, "because the transition to a lower-carbon economy requires significant and, in some cases, disruptive changes across economic sectors and industries in the near term, financial policymakers are interested in the implications for the global financial system, especially in terms of avoiding financial dislocations and sudden losses in asset values" (2017:iii).

The reality is that if all business does not face up to the enveloping threats and opportunities of climate change, carbon intensity will continue to increase towards the worst case projected scenario, and beyond, of the IPCC at 4 per cent of global warming that will undoubtedly precipitate the non-linear compounding of climactic catastrophes that will endanger civilisation let alone business survival. A high rate of decarbonisation is required to keep global warming below 2 per cent that will demand virtually zero-carbon emissions by the end of the century, a goal that will require comprehensive commitment from corporations and directors.

As Figure 2 indicates the rate of progress towards decarbonization is growing: carbon intensity (emissions per dollar of GDP) fell by 2.6 per cent in 2016, doubling the rate of reduction since 2000. However, this falls short of the 3 per cent average decarbonization rate required to achieve the national targets pledged in the Paris agreement. More starkly this agreed rate remains at half the required rate of $6.3 \%$ decarbonization per annum if global warming is to be kept below two degrees which was the ultimate objective of the Paris Agreement (PWC 2017). 


\section{Figure 2 Reducing Carbon to Zero Emissions by the End of the Century}

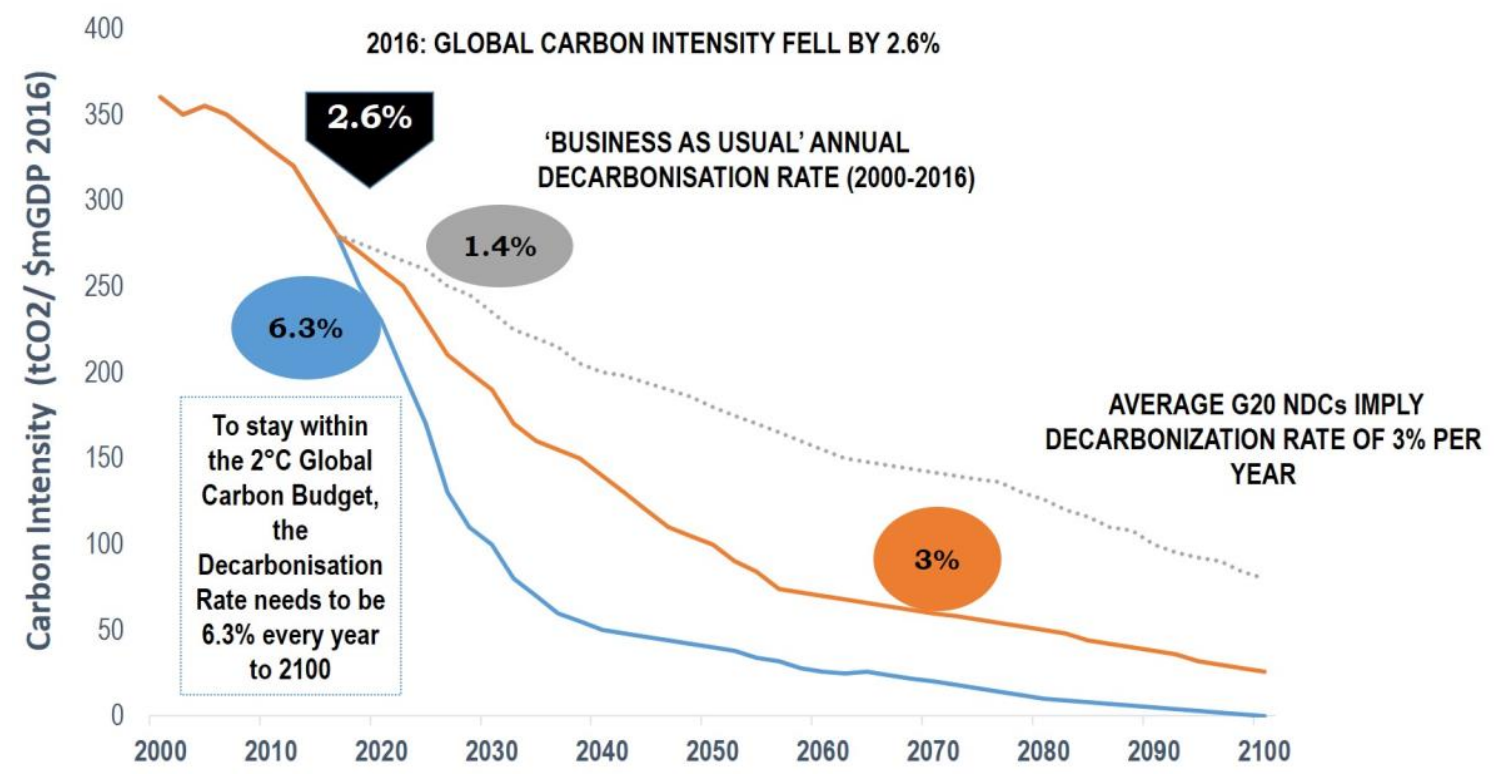

Source: Adapted from PWC (2017)

(Nationally Determined Contributions (NDCs))

What this suggests is at both national government and business levels there must be redoubling of efforts towards decarbonization. That this is achievable is illustrated by the UK (7.7 per cent decarbonization in 2015-2016) and the vast economy of China (6.5 per cent decarbonization in 2015-2016) (PWC 2017). While the emissions reduction is mainly attributed to slower economic growth and the transition from coal to gas, the commitment to decarbonization is fueled by the rapid growth of renewables (wind, geothermal/biomass and solar) offering decentralized, digital and decarbonized energy at progressively lower cost than the fossil fuels that are now in a long but marked process of reduction and displacement (PWC 2017). The context is now set for the contest around a new zeitgeist 
of sustainability in business that will define investment, strategy and operations in the $21^{\text {st }}$ century.

\section{The New Zeitgeist of Sustainability in Corporate Governance}

Climate change throws up many confronting challenges to corporations and the law, which are presently the subject of intense debate (UN Global Compact 2011: Agrawala et al 2013; CDP 2014; Craig 2010; Craig and Benson; Richardson et al 2011; Phelan 2011; UNEP 2010; IEA 2013; KPMG 2012; Caldecott et al 2015; Seki and Clarke 2013; Clarke 2007a; 2007b; 2016a). In the Final Report (2015) of the American Bar Association (ABA) Task Force on Sustainable Development the scale of the challenge in achieving sustainability involving the "promotion of environmental protection, social justice, and economic/financial responsibility at the same time, with the overall objective of promoting human well-being for present and future generations... Sustainability is intended to address two significant and related problems - widespread environmental degradation, including climate disruption, and large-scale extreme poverty. The root causes of these problems, in turn, are understood to be unsustainable patterns of production and consumption as well as a very large and still growing population" (American Bar Association 2015:1).

In a remarkable intervention at Loyds insurers of London on 29 September 2015, Mark Carney the Governor of the Bank of England and Chairman of the Financial Stability Board (established by the G20 to monitor and review global financial and economic stability) highlighted that while a classical problem of environmental economics is the Tragedy of the Commons - the despoliation of common property through over-use, climate change is also a Tragedy of the Horizon - that because the catastrophic impact of climate change is beyond the traditional horizon of most actors, it is imposed as a cost on future generations as the current generations has little direct incentive to fix this (Carney 2015). That is the intervention to repair climate change is beyond the usual business cycle, 
political cycle, or horizon of regulators and other authorities (Risky Business 2015). The tragic paradox is that by the time climate change is considered a defining issue within the normal business and political cycle it will be too late to repair except at enormous cost.

Attempting to calculate the potential future costs involved, the G20 Finance Ministers asked the Financial Stability Board to consider how the financial sector could take account of the risks climate change posed for the financial system. Carney identifies three channels through which climate change can impact on financial stability:

- Physical risks: the impact today on insurance liabilities and the value of financial assets arising from climate related events such as floods and storms that damage property and disrupt trade;

- Liability risks: the impacts that could arise if parties suffering loss or damage from the effects of climate change seek compensation from those they hold responsible. These claims could come decades into the future, but could potentially hit carbon resources companies and emitters hard, and if they have liability cover would hit their insurers the hardest.

- Transition risks: the financial risks resulting from the process of adjusting towards a low carbon economy as changes in policy, technology, and physical risks prompt a reassessment of the value of a large range of assets as costs and opportunities become apparent (Carney 2015:6).

These risks can be minimised by an early and predictable path of transition to anticipating the consequences of a world two degrees warmer, or alternatively the risks can be maximised by waiting for the consequences to occur and allow jump-to-distress pricing to ruin businesses (Carney 2015:6). Already since the 1980s the number of weather related loss events has tripled for the insurance industry and the inflation-adjusted insurance losses have increased from an annual average of around $\$ 10$ billion in the 1980s, to around $\$ 50$ billion over the past decade (Prudential Regulation Authority 2015; Munich $\operatorname{Re} 2015)$. 
Corporations have a central role to play in the two main strategies for combating climate change by mitigation and adaptation. Diminishing the potentially catastrophic consequences of the increasing impact of climate change will require urgent efforts to reduce carbon emissions. Corporations are required to make a major contribution to emissions mitigation, and if they refuse to do so will face reputational damage, higher energy costs, legal costs and fines from increasingly rigorous emissions regulation. More critically, they may find it increasingly difficult to transfer the risk they encounter through insurance, and also discover they are being deserted by investors and credit providers concerned at the exposure to emissions intensive sectors, immense stranded assets, and declining industries (Barker 2015). Equally corporations will be fully engaged in the efforts at adaptation to climate change involving actions to moderate the harm of climate change, or to pursue opportunities to ameliorate the harmful effects of climate change. While the primacy of the effort to mitigate climate change is indisputable, the fact that past emissions will determine a certain degree of climate change, make adaptation necessary.

Corporations that prove incapable of adaption to the physical impact of climate change will be vulnerable to interruptions in their business operations and supply chain, potential damage to plant and infrastructure, and water and other raw materials scarcity. The two corporate strategies of mitigation and adaptation are connected, since significant emissions mitigation is necessary to achieve effective adaptation by minimising vulnerability to environmental shocks and enhancing resilience (Barker 2015). We have clearly passed the stage where the responsibility for mitigation and adaptation relating to climate change could largely be regarded as belonging solely to government. The hazards associated with climate change are both considerable and pervasive, and are characterised by their complexity and inter-connectedness. This is a complex wicked problem, that requires complex wicked solutions. The dramatic climactic discontinuities caused by climate change "may give rise to cascading risks of potentially unforeseeable magnitude" (Godden et al 2013:235; Bishop 2012; Crane $t$ al 2008). Therefore climate change cannot be framed as one of technical risk management for government and 
specialists, it is the responsibility of everyone, but particularly those in leadership positions in organisations that have a significant environmental impact: "..Although risk management is a responsibility of corporations and government agencies which carry out risk assessments as part of their legal and actuarial responsibilities, it now seems to be required of all actors - as risk is shifted from collective institutions and specialised systems to individuals. Faced with systemic and pervasive risk, the individual must plan and measure contingencies and adopt 'actuarial rationality"' (Godden et al 2013:237). As Godden et al argue:

“..Climate change adaptation measures require a more sophisticated model of legal, regulatory and governance structures in order to develop effective responses... Adaptation to climate change, therefore, must negotiate the need for heightened complexity in governance, but also seek to deconstruct conventional simplifying mechanisms such as clear boundaries between public and private spheres. Embracing such complexity is not always palatable, but re-invoking simplifying assumptions about appropriate legal and institutional forms may be detrimental if robust governance for climate risk adaptation is the overarching objective" (Godden et al 2013:255).

How climate change impacts upon the interpretation of directors' duties is now being examined. As Barker elucidates with reference to climate change international law has thus far concentrated upon the broad areas of taxing of emissions, protecting the environment with emissions standards and disclosures, and planning. Litigation has mainly occurred in planning and environmental protection regarding high-emitting projects or vulnerable environments, with the law recognising the impact of anthropogenic climate change and the risks of failure to mitigate emissions, and adapt to its consequences (Barker (2013:10; Peel 2011; Peel and Osofsky 2013; McDonald 2011; Lord et al 2012; Agnew 2012). Barker concludes that at this stage the question of liability for climate change has revolved around mitigation and its cost, while the issue of damage caused by climate change impacts remains at an embryonic stage: "Plaintiffs have found duty and causation (or, in a climate change context, 'attribution') to be near 'insurmountable' evidentiary hurdles. This is primarily due to the disconnect between the 
global nature of emissions and their collective, cumulative effect, versus the localised nature of their impacts" (Barker 2013:12).

As Barker convincingly argues (in an Australian legal context, that has similar implications for other jurisdictions), there will be in the future no safe harbour for the irresponsible director:

“...Even where directors' subjective bona fides are not in question, passivity, reactivity or inactivity on climate change governance is increasingly likely to contravene the duty of care and diligence under section 180(1) of the Corporations Act, and increasingly unlikely to satisfy the 'business judgment rule' defence under section 180(2). This includes governance strategies that emanate from climate change denial, a failure to consider its (impacts due to ignorance or unreflective assumption, paralysis caused by the inherent uncertainty of its magnitude and timing, or a default to a base set by regulators or industry peers). In addition, even considered decisions to prevail with 'business as usual' are increasingly unlikely to satisfy the duty (or the business judgment rule defence) particularly if they are the product of a conventional methodology that fails to recognise the unprecedented challenges presented by an erratically changing climate. In addition, whilst unorthodox, it is reasonably arguable that a failure to actively consider the impacts of climate change may also breach the duty to act in good faith in the best interests of the corporation under section 181. Accordingly, directors who do not proactively respond to the commercial risks and opportunities of climate change, now, may be held to account under the Corporations Act if corporate value becomes impaired into the future" (Barker 2013:4; Sethi and Schepers 2014).

While international agencies remain silent on the question of the implications for directors' duties of climate change, this reserve is unlikely to continue. As the American Bar Association contends: "Corporate sustainability efforts in particular have been growing in scope and intensity over the past few years. In translating the broad objectives of sustainability into specific practices, businesses are guided to a growing degree by private systems of governance. These include sustainability-related codes of 
organizational behavior, including the CERES (Coalition for Environmentally Responsible Economies) Principles, the UN Global Compact, the UN Guiding Principles on Business and Human Rights, the Global Reporting Initiative standards on sustainability reporting, and the International Chamber of Commerce's Charter for Sustainable Development" (ABA 2015:3). There are indeed many hundreds of policy initiatives led by institutions across the world. Existing initiatives vary in their status from laws to voluntary guidance, from the UN to government, and through to civil society; in their scope from limiting greenhouse gas emissions to tackling broader environmental risks; and in their ambition, from demanding simple disclosure to full explanations of mitigation and divestment strategies. These institutional initiatives have increasing influence and authority as the science and policy base that supports them becomes more profound. In aggregate over 90\% of FTSE 100 firms and 80\% of Fortune Global 500 firms participate in these various initiatives (Carney 2015:14).

In the past corporate objectives described as 'wealth generating' too frequently have resulted in the loss of well-being to communities and the ecology. But increasingly in the future the licence to operate will not be given so readily to corporations and other entities. A licence to operate will depend on maintaining the highest standards of integrity and practice in corporate behaviour. Corporate governance essentially will involve a sustained and responsible monitoring of not just the financial health of the company, but the social and environmental impact of the company. As ABA states "legal tools, the legal profession, and the rule of law can make important contributions and are an integral component of efforts to achieve sustainability, especially by promoting good governance" (Carney 2015:14).

\section{Reconceptualising Fiduciary Duty}

Given the enormity of the environmental and social threat to existence that humanity has encountered in recent decades, and the range and extent of the civil, professional, business, and governmental response to the impending crisis of climate change, it is 
curious that internationally, while there have been substantial reforms in environmental and related law, there has been comparatively little change in corporate law or in the duties of directors (Clarke 2013; Clarke 2015). One explanation of this paradox is the view that directors in pursuing the success of the company already are able and willing to take into account the impact of environmental and social changes, and to develop strategies to mitigate or adapt to these threats. That is directors are becoming increasing aware of the elephant in the boardroom, and are interpreting their duties in this context:

"It is estimated that the top 100 environmental externalities cost the global economy around US $\$ 4.7$ trillion a year, according to a 2013 report commissioned by The Economics of Ecosystems and Biodiversity (TEEB) for Business Coalition, (now known as the Natural Capital Coalition). The report observes that half of all existing corporate profits are at risk if the costs associated with natural capital were to be internalised through market mechanisms, regulation or taxation. A water shortage, for example, would have a 'severe' or 'catastrophic' impact on 40\% of Fortune 100 companies" (CIMA 2014: 6-7).

Company directors are beginning to realise that material and insistent evidence "posits climate change as a squarely financial concern: not only consistent with, but prerequisite to, the maximisation of wealth, and therefore imperative to directors' oversight of risk and strategy" (Barker 2013:13). That is, directors will incorporate environmental and social responsibility into their decision making as part of a balanced assessment of the risks and opportunities facing the company. Barker continues: "As the impacts of climate change continue to intensify, so too does the likelihood that corporations who are not strategically positioned to manage them will be placed at a significant competitive disadvantage. This undermines the maximisation of corporate wealth or value and, in some cases, may raise the prospect of insolvency. In such circumstances ...the regulator charged with maintaining the integrity of the market, may hold directors to account for any breach of the corporate governance laws. And shareholders and creditors may look to recover their losses from directors and their deep-pocketed insurers" (Barker 2013:13). 
Considerable attention has been focused on the effort to reform the interpretation of directors' duties in the US with corporate constituency statutes; and the development of Bcorporations with more inclusive objectives, principles which Senator Elizabeth Warren wished to extend to all large US corporations in her Accountable Capitalism (2018) bill. In the UK on Section 172 (1) of the Companies Act 2006, which states directors should have regard to the impact of the company's operations on the community and environment has attracted much interest. Yet, imperceptibly wider changes may have been occurring in the interpretation of directors' duties in practice (which were always more carefully balanced than the naked tenets of shareholder primacy urged).

In fact the narrow strictures of shareholder value routinely neglected the ethical foundation of business, as a University of Cambridge study argues "...the separation of ethics from fiduciary duty assumes that the overriding interest of savers is to make the most money possible, regardless of the social and environmental consequences - a view that has never been verified through robust empirical research but, rather, imputed without consent" (ISL 2014; Clarke and Chanlat 2009; Clarke 2016b; Clarke and Boersma 2017). The understanding of directors' fiduciary duty is changing in the $21^{\text {st }}$ century, and both company directors and investors need to respond. As a UNEP international survey of asset owners, investment managers, lawyers and regulators concludes, "Failing to consider long-term investment value drivers, which include environmental, social and governance issues, in investment practice is a failure of fiduciary duty" (UNEP 2015:9)

The re-evaluation of fiduciary duty is presently taking place, and will prove to be profound, as Watchman states, "The concept of fiduciary duty is organic, not static. It will continue to evolve as society changes, not least in response to the urgent need for us to move towards an environmentally, economically and socially sustainable financial system" (UNEP 2015: 9). What is occurring is the widespread and insistent development of soft law to deal with the wicked complexities the overwhelming emergency of climate change has exposed. While soft law has its limitations, it also may be applied intelligently 
and promptly to deal with changing circumstances, and can be translated into hard law when required and possible. "The term 'soft law' entered the international lexicon in the 1970s as a descriptive and differentiating phrase: soft law was anything that was not in fact, hard law promulgated by a government body authorised to enact it, but that nonetheless was designed to affect, or actually behaviour that might in time solidify into hard law or otherwise affect the development of hard law" (Bjorklund 2012:51). Soft law does possess authority, the UN Declaration of Human Rights is the most translated document in the world (in 370 languages), and yet has no legal status (UN 2015).

There are many current issues that will sharpen company directors' sense of fiduciary duty regarding the materiality of environmental and social concerns. The issue of 'Loss and Damage' from climate change (the impact of climate change not mitigated by reductions in emissions) is now on the agenda of the United Nations Framework Convention on Climate Change, with discussion of the case for compensation (UNFCCC 2013). Addressing the insurance industry Mark Carney stated, "Participants in the Lloyd's market know all too well that what appear to be low probability risks can evolve into large and unforeseen costs over a longer timescale. Claims on third-party liability insurance - in classes like public liability, directors' and officers' and professional indemnity - could be brought if those who have suffered losses show that insured parties have failed to mitigate risks to the climate; failed to account for the damage they cause to the environment; or failed to comply with regulations... Cases like Arch Coal and Peabody Energy - where it is alleged that the directors of corporate pension schemes failed in their fiduciary duties by not considering financial risks driven at least in part by climate change (Roe v Arch Coal Inc et al 2014; Lynn v Peabody Energy 2015) - illustrate the potential for long-tail risks to be significant, uncertain and non-linear" (Carney 2015:9).

Mark Carney from a Bank of England and Financial Stability Board perspective set out starkly the implications for the resources industries of the IPCC's estimate of a carbon budget necessary to limit global temperature rises to 2 degrees above pre-industrial levels: 
a carbon budget that amounts to between $1 / 5$ th and 1/3rd of the world's proven reserves of oil, gas and coal.

"If that estimate is even approximately correct it would render the vast majority of reserves "stranded" - oil, gas and coal that will be literally unburnable without expensive carbon capture technology, which itself alters fossil fuel economics. The exposure of UK investors, including insurance companies, to these shifts is potentially huge. $19 \%$ of FTSE 100 companies are in natural resource and extraction sectors; and a further $11 \%$ by value are in power utilities, chemicals, construction and industrial goods sectors. Globally, these two tiers of companies between them account for around one third of equity and fixed income assets" (Carney 2015: 10).

\section{Table 3 Integrated Governance: Disclosures and Action}

\begin{tabular}{|c|c|c|c|}
\hline Governance & Strategy & Risk Management & Metrics and Targets \\
\hline $\begin{array}{l}\text { Disclose the organization's } \\
\text { governance around climate-related } \\
\text { risks and opportunities. }\end{array}$ & $\begin{array}{l}\text { Disclose the actual and potential } \\
\text { impacts of climate-related risks and } \\
\text { opportunities on the organization's } \\
\text { businesses, strategy, and financial } \\
\text { planning where such information is } \\
\text { material. }\end{array}$ & $\begin{array}{l}\text { Disclose how the organization } \\
\text { identifies, assesses, and manages } \\
\text { climate-related risks. }\end{array}$ & $\begin{array}{l}\text { Disclose the metrics and targets } \\
\text { used to assess and manage relevant } \\
\text { climate-related risks and } \\
\text { opportunities where such } \\
\text { information is material. }\end{array}$ \\
\hline Recommended Disclosures & Recommended Disclosures & Recommended Disclosures & Recommended Disclosures \\
\hline $\begin{array}{l}\text { a) Describe the board's oversight of } \\
\text { climate-related risks and } \\
\text { opportunities. }\end{array}$ & $\begin{array}{l}\text { a) Describe the climate-related risks } \\
\text { and opportunities the } \\
\text { organization has identified over } \\
\text { the short, medium, and long } \\
\text { term. }\end{array}$ & $\begin{array}{l}\text { a) Describe the organization's } \\
\text { processes for identifying and } \\
\text { assessing climate-related risks. }\end{array}$ & $\begin{array}{l}\text { a) Disclose the metrics used by the } \\
\text { organization to assess climate- } \\
\text { related risks and opportunities in } \\
\text { line with its strategy and risk } \\
\text { management process. }\end{array}$ \\
\hline \multirow[t]{2}{*}{$\begin{array}{l}\text { b) Describe management's role in } \\
\text { assessing and managing climate- } \\
\text { related risks and opportunities. }\end{array}$} & $\begin{array}{l}\text { b) Describe the impact of climate- } \\
\text { related risks and opportunities on } \\
\text { the organization's businesses, } \\
\text { strategy, and financial planning. }\end{array}$ & $\begin{array}{l}\text { b) Describe the organization's } \\
\text { processes for managing climate- } \\
\text { related risks. }\end{array}$ & $\begin{array}{l}\text { b) Disclose Scope 1, Scope 2, and, if } \\
\text { appropriate, Scope } 3 \text { greenhouse } \\
\text { gas (GHG) emissions, and the } \\
\text { related risks. }\end{array}$ \\
\hline & $\begin{array}{l}\text { c) Describe the resilience of the } \\
\text { organization's strategy, taking } \\
\text { into consideration different } \\
\text { climate-related scenarios, } \\
\text { including a } 2^{\circ} \mathrm{C} \text { or lower scenario. }\end{array}$ & $\begin{array}{l}\text { c) Describe how processes for } \\
\text { identifying, assessing, and } \\
\text { managing climate-related risks } \\
\text { are integrated into the } \\
\text { organization's overall risk } \\
\text { management. }\end{array}$ & $\begin{array}{l}\text { c) Describe the targets used by the } \\
\text { organization to manage climate- } \\
\text { related risks and opportunities } \\
\text { and performance against targets. }\end{array}$ \\
\hline
\end{tabular}

Source: Adapted from TCFD (2017)

The proposals of the G20 supported Task Force on Climate-Related Financial Disclosures (TCFD) of the Financial Stability Board has addressed these concentrations of carbon- 
related assets and determined on a new disclosure regime to promote informed investment, credit, and insurance under-writing throughout the finance sector to ensure that exposure to climate-related risks are fully understood and combatted. This is model of integrated governance linking disclosure to action (Table 3). The objectives of the TCFD are much more than the disclosure of material information on climate-related risk - it is to inform and energize the transition from carbon because of the acute risks involved, and to place in context the huge opportunities of decarbonization in terms of resource efficiency, new energy sources, and new products and services. This new climate related disclosure regime places on notice the entire international financial institutions to be signally more responsible with regard to the perilous condition of the planet. Yet there is the other more promising side of the ledger if corporations are astute enough to realise it. "On the other hand, financing the de-carbonisation of our economy is a major opportunity for insurers as long-term investors. It implies a sweeping reallocation of resources and a technological revolution, with investment in long-term infrastructure assets at roughly quadruple the present rate" (Carney 10-11).

\section{Figure 3 The Widening Scope of Director's Duties:} The Increasing Impact of Social and Environmental Responsibility 


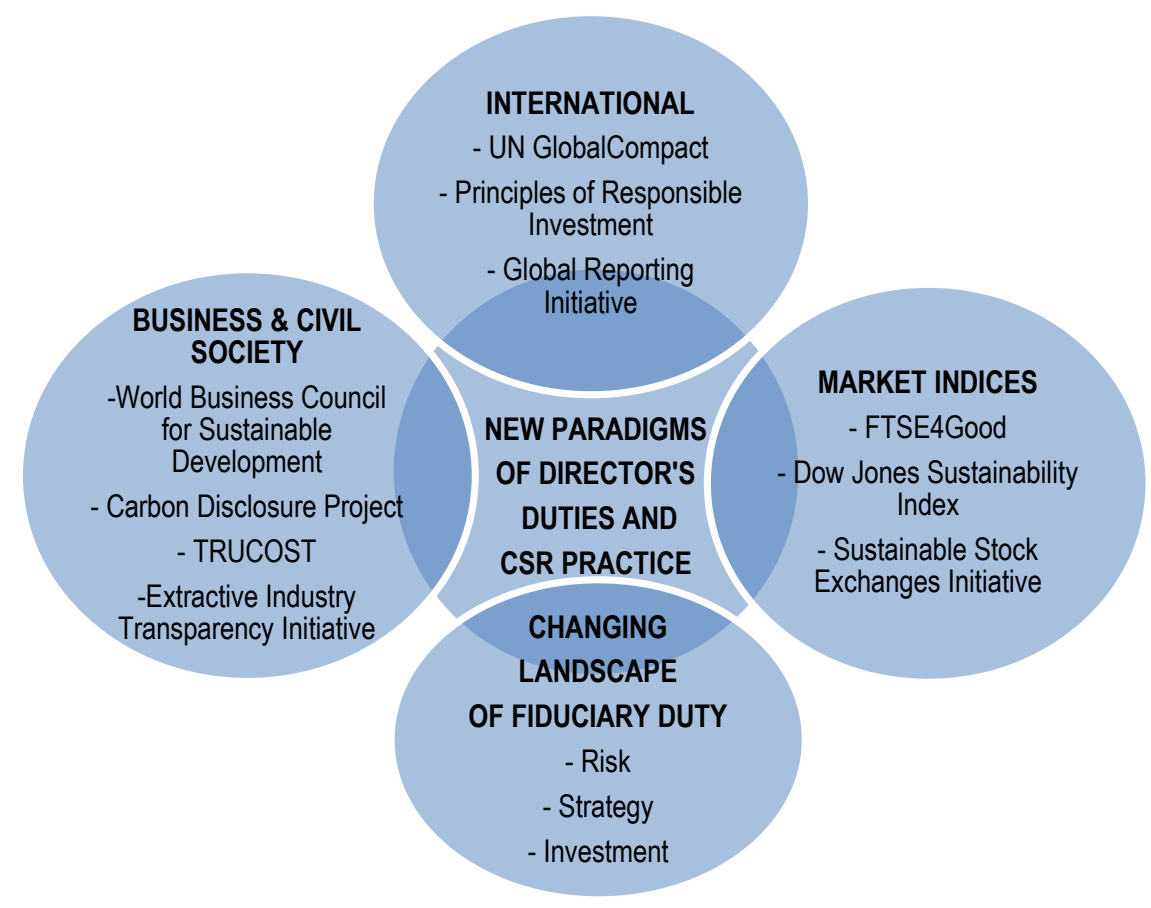

The gathering scale of the international, national, market and business, and civil society campaign for corporate social and environmental responsibility presents an irresistible challenge to corporations and directors to rethink their mission in the direction of sustainability (Figure 3) (Hart 1995; GRI 2011; PRI 2015; FTSE 2011; European Commission 2015; Bishop 2012; Trucost/TEEB 2013; PDC 2015; WBCSD 2015; EITI 2015a; SSEI 2015; UN Global Compact 2015; WFE 2017). We are now engaging in a profound process of institutional transformation around the imperatives of sustainability. This transformation may be understood in terms of Fligstein and McAdam's Theory of Fields (2012) which conceives how the commitment of skilled people may upset established routines and build new political and organizational fields. The core of the argument examines how people deploy resources, build relationships, and forge new practices. In doing this they place agency in a new and more visible light (Elkington, J. (2005); AccountAbility/United Nations Global Compact 2014; Sukhdev et al 2014; Fay et al 2015; MacArthur 2015; Fucks 2015; Helm 2015; UN 2015; OECD 2017; Benn et al 2018).

\section{Conclusions}


Perhaps never in the history of human civilisation has the world faced a more consuming challenge than climate change, or more terrible consequences if a sustainable solution is not achieved. Yet the field of sustainability has assembled the most remarkable constellation of talents and ideals stretching from engineers and life scientists, through community activists and institutional entrepreneurs, to lawyers, company directors and politicians. Tackling the greatest problem of humanity, and some of the most deep-seated corporate interests in business as usual, are an array of individuals and institutions with a vision of a sustainable future. The contest for a new sustainable zeitung will continue for many decades to come, and the outcome will determine the future of human civilisation as well as planetary sustainability. It is clear though that the pace of change towards a sustainable economy will only continue to accelerate if there is significant, insistent and sustained pressure upon business to contribute to this goal from all stakeholders. Coalitions of institutions have sponsored initiatives for corporate responsibility that have driven collaborative business action for responsible business practices (Grayson and Nelson 2013: Nelson 2002; ISL 2014). The vast institutional development internationally around the theme of corporate social and environmental responsibility and sustainability is ultimately going to prove irresistible, the only question is will this occur before severe damage to the planet is irreversible?

\section{REFERENCES}

ABC News (2010) BP's Dismal Safety Record, 27 May 2010, http://abcnews.go.com/WN/bps-dismal-safety-record/story?id=10763042

AccountAbility/United Nations Global Compact, (2014) Growing Into Your Sustainability Commitments: A Roadmap for Impact and Value Creation, AccountAbility/United Nations Global Compact 
Agnew, R. (2012) The End of the World as We Know It: the Advance of Climate Change from a Criminological Perspective, in R White (ed), Climate Change from a

Criminological Perspective, Springer

Agrawala, S., Carraro, M., Kingsmill, N., Lanzi, E., Mullan, M. and Prudent-Richard, G. (2013) Private Sector Engagement in Adaptation to Climate Change: Approaches to Managing Climate Risks, OECD Environmental Working Papers, No. 39, OECD Publishing, revised February 2013 http://www.oecdilibrary.org/docserver/download/5kg221jkf1g7.pdf?expires=1443415479 \&id=id\&accname=guest\&checksum=D165B27080655A6E2C2B02C016204C2D;

American Bar Association (2015) Final Report of the American Bar Association Task Force on Sustainable Development, 30 July 2015, p1, http://www.americanbar.org/content/dam/aba/administrative/environment_energy_resourc es/resources/final_sdtf_aba_annual_08-2015.authcheckdam.pdf

Banerjee, S.B. (2012) Critical Perspectives on Business and the Natural Environment, in, P.Bansal and A.Hoffman (eds), The Oxford Handbook of Business and the Natural Environment, Oxford University Press

Barker, S. (2013) Directors'Duties in the Anthropocene: Liability for Corporate Harm Due to Inaction on Climate Change, Corporate Law, Economics and Science Association, http://www.clesa.net.au/blog/2015/1/14/directors-duties-in-the-anthropocene-liability-forcorporate-harm-due-to-inaction-on-climate-change

BBC (2009) Why Did Copenhagen Fail to Deliver a Climate Deal?, BBC NEWS (Dec. 22, 2009), http://news.bbc.co.uk/2/hi/8426835.stm

Benn, S., Edwards, M. and Williams, T. (2015) Organizational Change for Corporate Sustainability, Fourth Edition, London: Routledge

Benoit, C. and Vickery-Niederman, G. (2010) Social Sustainability Assessment Literature Review, White Paper 102, Sustainability Consortium, Arizona State University and University of Arkansas, December 2010

http://www.sustainabilityconsortium.org/wpcontent/themes/sustainability/assets/pdf/white papers/Social_Sustainability_Assessment.pdf;

Bishop, J. (2012) (ed), The Economics of Ecosystems and Biodiversity, TEEB, http://www.teebweb.org/media/2012/01/TEEB-For-Business.pdf

Bjorklund, A.K. (2012) Assessing the Effectiveness of Soft Law Instruments in International Investment Law, Edward Elgar, in Andrea K. Bjorklund and August

Reinisch (2012) International Investment Law and Soft Law, Edward Elgar 
Bowen, F. (2014) After Greenwashing: Symbolic Corporate Environmentalism and Society, Cambridge University Press

Brinded, M. (2011) Upstream International, at the FT Global Energy Leaders Summit, London, June 28, 2011

Bureau of Ocean Energy Management (2010) Regulation and Enforcement, Report Regarding the Causes of the April 202010 Maconda Well Blowout, 14 September 2011, http://docs.lib.noaa.gov/noaa_documents/DWH_IR/reports/dwhfinal.pdf

Caldecott, B., Dreicks, G. and Mitchell, J. (2015) Stranded Assets and Subcritical Coal: The Risk to Companies and Investors, Stranded Assets Program, Smith School of Enterprise and the Environment, Oxford University http://www.smithschool.ox.ac.uk/research-programmes/strandedassets/Stranded\%20Assets\%20and\%20Subcritcial\%20Coal\%20\%20The\%20Risk\%20to\%20Investors\%20and\%20Companies\%20-\%20April15.pdf

Carney, M. (2015) Breaking the Tragedy of the Horizon - Climate Change and Financial Stability, 29 September 2015, http://www.bankofengland.co.uk/publications/Documents/speeches/2015/speech844.pdf

(CCES 2015) Outcomes of the UN Climate Change Conference in Paris, Centre for Climate and Energy Solutions, http://www.c2es.org/docUploads/cop-21-paris-summary12-2015-final.pdf

CDP (2014) Climate Change and Profitability, CDP S \& P 500 Climate Change Report,

Carbon Disclosure Project, https://www.cdp.net/CDPResults/CDP-SP500-leaders-report2014.pdf

CIMA (2014) Accounting for Natural Capital: The Elephant in the Boardroom, London: Chartered Institute of Management Accountants

http://www.cimaglobal.com/Documents/Thought_leadership_docs/Sustainability\%20and \%20Climate\%20Change/CIMA-accounting-for-natural-capital.pdf

Clarke,T. and M. Boersma (2017) The Governance of Global Value Chains: Unresolved Human Rights, Environmental and Ethical Dilemmas in the Apple Supply Chain in China, Journal of Business Ethics, 133, 395-419

Clarke, T. (2016a) The Widening of Directors' Duties: The Increasing Impact of Corporate Social and Environmental Responsibility, Seattle University Law Review, 39, 531-602

Clarke, T. (2016b) The Continuing Diversity of Corporate Governance: Theories of Convergence and Variety, Ephemera: Theory and Politics in Organization, 
Clarke T (2015) The Long Road to Reformulating the Understanding of Directors' Duties: Legalising Team Production Theory, Seattle University Law Review, Vol 38, 433-487

Clarke T (2013a) Deconstructing the Mythology of Shareholder Value 3 Accounting, Economics, and Law, 3, 1, pp. 15-42

Clarke, T. and Chanlat, J.F. (2009) European Corporate Governance: Readings and Perspectives, London: Routledge

Clarke, T., (2007a). The Evolution of Directors Duties: Bridging The Divide Between Corporate Governance And Corporate Social Responsibility, Journal Of General Management, March 32(3): 1-27

Clarke, T., (2007). The Materiality of Sustainability: Corporate Social and Environmental Responsibility as Instruments of Strategic Change, in Benn, S., and Dunphy, D., Corporate Governance and Sustainability, London and New York: Routledge, pp 219-251

Craig, R.K. (2010) "Stationarity is Dead" - Long Live Transformation: Five Principles for Climate Change Adaptation Law, 24 Harvard Environmental Law Review 10, 22 et seq;

Crane, A., Matten, D., and Moon, J., (2008) Ecological Citizenship and the Corporation: Politicising the New Corporate Environmentalism, Organization and Environment 21,371-389

Crane, A., Matten, D. and Spence, L.J. (2014) Corporate Social Responsibility: Readings and Cases in a Global Context, London: Routledge

CSSR (2017) U.S. Global Change Research Program, Climate Science Special Report, U.S. Global Change Research Program http://www.globalchange.gov/content/cssr

Deepwater Horizon Study Group (2011) Final Report on the Investigation of the Maconda Well Blowout, Centre for Catastrophic Risk Management, 1 March 2011, p5, http://ccrm.berkeley.edu/pdfs_papers/bea_pdfs/dhsgfinalreport-march2011-tag.pdf

Delmas, M.A. and Burbano, V.C. (2011) The Drivers of Greenwashing, California Management Review, 54, 64-87

DJSB (2015a) Results Announced for 2015 Dow Jones Sustainability Indices Review, http://www.sustainability-indices.com/images/150910-djsi-review-2015-en-vdef.pdf

EITI (2015a) The Importance of Natural Resources for Government Revenues, 2015, p1, http://progrep.eiti.org/2015/glance/importance-natural-resources-government-revenues 
Elkington, J. (2005). Government in the Chrysalis Economy, in R. Olsen and D. Rajeski (eds), Environmentalism and the Technologies of Tomorrow: Shaping the Next Industrial Revolution, Washington DC: Island Press, 133-142

EIU (2015) The Cost of Inaction: Recognising the Value at Risk from Climate Change,

Economist Intelligence Unit

https://www.eiuperspectives.economist.com/sites/default/files/The\%20cost\%20of\%20inac $\underline{\text { tion_0.pdf }}$

European Commission (2015a) Circle Economy, http://www.circleeconomy.com/circular-economy/;

Ewing, J. (2018) Volkswagen Suspends Top Lobbyist Amid Inquiry Into Diesel Tests on Monkeys, New York Times, 30 January 2018

Fay, M., S.Hallegatte, A. Vogt-Schilb, J. Rozenber, U. Narlock, T. Kerr (2015) Decarbonising Development: Three Steps to a Zero-Carbon Future, World Bank

Financial Times (2015) BP Finalises \$20.8 billion Deepwater Horizon Settlement, 6 October 2015

Financial Times (2015) Boardroom Politics at Heart of VW Scandal, 4 October 2015

Fligstein, N. and McAdam, D. (2012) A Theory of Fields, Oxford University Press, 2012 FTSE (2011) FTSE4Good: Ten Years of Impact and Investment, FTSE, http://www.ftse.com/products/downloads/FTSE4Good_10_Year_Report.pdf FTSE (2015) Index Inclusion Rules for the FTSE4Good Index Series, FTSE, http://www.ftse.com/products/downloads/F4G-Index-Inclusion-Rules.pdf

Fücks, R. (2015) Green Growth, Smart Growth: A New Approach to Economics, Innovation and the Environment, Anthem Press (originally published as Carl München, Die Grüne Revolution, 2013

Gillespie, E. (2008) Stemming the Tide of Greenwash, Consumer Policy Review, 18, 7983

Godden,L., Rochford,F., Peel,J., Caripis,L. and Carter,R. (2013) Law, Governance and Risk: Deconstructing the Public-Private Divide in Climate Change Adaptation, UNSW Law Journal, Vol 61, 1, 224-255, P235

Grayson,D., Nelson, J. (2013) Corporate Responsibility Coalitions: The Past, Present, and Future of Alliances for Sustainable Capitalism, Stanford University Press 
Green Biz/Trucost (2015) The State of Green Business 2015

https://www.greenbiz.com/microsite/state-green-business

Greenpeace, (1992) Greenpeace Book on Greenwash, Greenpeace

Greenpeace, (2012) Greenwash + 20: How Some Powerful Corporations Are Standing in the Way of Sustainable Development, Greenpeace

http://www.greenpeace.org/international/Global/international/publications/RioPlus20/Gre enwashPlus20.pdf

GRI (2011) GRI and ISO 2600: How to Use the GRI Guidelines in Conjunction with ISO 26000, Global Reporting Initiative,

https://www.globalreporting.org/resourcelibrary/How-To-Use-the-GRI-Guidelines-In-

Conjunction-With-ISO26000.pdf

Guardian (2015) Deepwater Horizon: BP Got 'Punishment It Deserved' Loretta Lynch Says, 6 October 2015

Hackmann H. and Boulton, G. (2016) Science for A Sustainable and Just World: A New Framework for Global Science Policy, UNESCO Science Report - Towards 2030, UNESCOPublishing, pp12-14

Hart, S. (1995) A Natural-Resource-Based View of the Firm, The Academy of Management Review, 20, 4, 986-1014

Helm, D. (2015) Natural Capital: Valuing the Planet, New Haven and London: Yale University Press

Hebb, T., Hawley, J., Hoepner, A. Neher, A., and Wood, D. (2015) The Routledge Handbook of Responsible Investment, Routledge

Hoffman,A. and Bansal, P. (2011) The Oxfrod Handbook on Business and the Natural Environment, Oxford University Press

Houser, T., Hsiang, S., Kopp, R., and Larsen,K. (2015) Economic Risks of Climate Change: An American Prospectus, Columbia University Press

IEA (2013) International Energy Agency, World Energy Outlook Special ReportRedrawing the Energy-Climate Map, OECD/IEA, 10 June 2013, 85

Klein, N. (2015) This Changes Everything: Capitalism vs. the Climate, Penguin

KPMG, Expect the Unexpected: Building Business Value in a Changing World, KPMG International 2012, https://www.kpmg.com/Global/en/IssuesAndInsights/ArticlesPublications/Documents/bui lding-business-value.pdf; 
IEA (2015) World Energy Outlook Special Briefing for Cop 21, International Energy Agency

ISL (2014) Institute for Sustainability Leadership, The Value of Responsible Investment: The moral, financial, and economic case for action, University of Cambridge, file:///C:/Users/990880/Downloads/ILG\%20the\%20value\%20of\%20responsible\%20inves tment.pdf

IPCC (2007) Climate Change 2007: Synthesis Report, Contribution of Working Groups I, II and III to the Fourth Assessment Report of the Intergovernmental Panel on Climate Change, Rajendra K Pachauri and Andy Reisinger (eds) (IPCC, 2007)

IPCC (2013) Climate Change 2013: The Physical Science Basis - Headline Statements from the Summary for Policymakers, Working Group I Contribution to the IPCC Fifth Assessment Report (IPCC, 27 September 2013);

IPCC (2014) Climate Change 2014: Impacts, Adaptation, and Vulnerability, Working Group II, Intergovernmental Panel on Climate Change, $\mathrm{p}$ vii https://www.ipcc.ch/pdf/assessment-report/ar5/wg2/WGIIAR5-FrontMatterA_FINAL.pdf

Kuhn, T. (1970) The Structure of Scientific Revolutions, University of Chicago Press

Lawrence, T.B., Suddaby, R. (2006) Institutions and Institutional Work, The Sage Handbook of Organization Studies, 2nd Edition, 215-254

Lord, R., Goldberg, S. Rajamani,L. and Brunnee,J. (eds) (2012) Climate Change Liability: Transnational Law and Practice, Cambridge University Press

Louche, C. and Hebb, T. (2014) Socially Responsible Investment in the $21^{\text {st }}$ Century, Emerald Group Publishing

Low Carbon Technology Partnership Initiative (2015) http://lctpi.wbcsdservers.org/

Lynn v Peabody Energy Corporation et al, Case: 4:15-cv-00916-AGF, United States District Court, Eastern District of Missouri, 11 June 2015

Lyon, T.P. and Maxwell, J., W., (2011) Greenwash: Corporate Environmental Disclosure Under Threat of Audit, Journal of Economics and Management Strategy, 20, 3-41

MacArthur, E. (2015) Growth Within: A Circular Economy Vision for a Competitive Europe, Ellen MacArthur Foundation, SUN, and McKinsey Centre for Business and Environment 
Munich Re (2015) September 2015, NatCatSERVICE (2015),

http://www.munichre.com/en/reinsurance/business/non-life/natcatservice/significantnatural-catastrophes/index.html

National Commission, Deepwater (2011) The Gulf Oil Disaster and the Future of Offshore Drilling, Report to the President, National Commission on the BP Deepwater Horizon Oil Spill and Offshore Drilling, 2011 http://www.gpo.gov/fdsys/pkg/GPOOILCOMMISSION/pdf/GPO-OILCOMMISSION.pdf

Nelson, J. (2002) Building Partnerships: Cooperation Between the United Nations System and the Private Sector, United Nations Publications

*Nelson, J. (2014) Corporate Social Responsibility: Emerging good practice for a new era, OECD Observer, OECD

http://www.oecdobserver.org/news/fullstory.php/aid/4369/Corporate_Social_Responsibilit y:_Emerging_good_practice_for_a_new_era.html\#sthash.Fy81yzUM.dpuf

New York Times (2015) Volkswagen Says 11 Million Cars Worldwide Are Affected in Diesel Deception, 22 September 2015

Natural Capital Coalition, http://www.naturalcapitalcoalition.org/about/coalitionmembers.html

OECD (2017) The Government Role in Mobilising Investment and Innovation in Renewable Energy, Investment Insights, OECD

OED (2012) Oxford English Dictionary, Oxford University Press

Otto F.E., (2015) Climate Change: Atribution of Extreme Weather, Nature Geoscience 8, 581-582 (2015)

Paulson, H. (2014). We US conservatives need to recognise climate change and find market solutions, The Observer 29 June 2014

PDC (2015) Portfolio Decarbonisation Coalition, http://unepfi.org/pdc/resources-2/

Phelan, L. (2011) Managing climate risk: extreme weather events and the future of insurance in a climate changed world, Journal of Environmental Management, 18, 4, 223

PRI (2015a) Principles of Responsible Investment, Report on Progress, PRI http://www.unpri.org/wp-content/uploads/PRI_Report-on-Progress_2015.pdf

Prudential Regulation Authority (2015) The Impact of Climate Change on the UK Insurance Sector, Bank of England, http://www.bankofengland.co.uk/pra/Documents/supervision/activities/pradefra0915.pdf 
*PWC (2017) Low Carbon Economy Index, London: PWC

https://www.pwc.co.uk/services/sustainability-climate-change/insights/low-carboneconomy-index.html

Rasche, A. and Waddock, S. (2014), Global Sustainability Governance and the UN Global Compact, Journal of Business Ethics, Vol 122, No 2, June III,209-216

*Reuter, E. and Ueberbacher, F. (2019) Corporate Strategies To Defend Social Irresponsibility: A Typology of Symbolic Compliance and Manipulation of Perceptions, in, Sales, A. (2019) Corporate Social Responsibility: Institutional and Organizational Perspectives, Springer

Richardson, K., Steffen, W. and Liverman, D. (2011) Climate change: global risks, challenges and decisions, Cambridge University Press, 2011

Roe v Arch Coal Inc et al, Case: 4:15-cv-00910-NAB, United States District Court, Eastern District of Missouri, 9 June 2015

Richardson, B.J. (2009) Keeping Ethical Investment Ethical: Regulatory Issues for Investing for Sustainability, Journal of Business Ethics, Vol 87, 4, 555

Risky Business (2015) The Economics of Climate Change in the United States, http://riskybusiness.org/

Risky Business (2014) A Climate Risk Assessment for the United States, June 2014

Sales, A. (2019) Corporate Social Responsibility: Institutional and Organizational Perspectives, Springer

Seki, T. and Clarke, T. (2013) The Evolution of Corporate Governance in Japan: The Continuing Relevance of Berle and Means, Seattle University Review, 37, 717-747

Sethi,S. and Schepers,D. (2014), United Nations Global Compact: The PromisePerformance Gap, Journal of Business Ethics, Vol 122, No 2, June III, 193-208

Shell (2002) "Minutes meeting of the Committee of Managing Directors", Shell, London, 22/23 July 2002 cited in Ten Kate, A. (2011) Royal Dutch Shell and its Sustainability Troubles, Friends of the Earth, Netherlands

Shell International (2008) Shell Energy Scenarios to 2050, Shell file:///C:/Users/Thomas\%20Clake/Desktop/Greening\%20the\%20Corporation/Greenwashi ng/shell-energy-scenarios2050.pdf

S \& P Dow Jones Indices, Volkswagen AG to be Removed from the Dow Jones Sustainability Indices, 29 September 2015 http://www.sustainabilityindices.com/images/150929-statement-vw-exclusion_vdef.pdf 
SSEI (2015) Sustainable Stock Exchanges Initiative, Model Guidance on Reporting ESG Information to Investors, A Voluntary Tool for Stock Exchanges to Guide Issuers, 2015, http://www.sseinitiative.org/wp-content/uploads/2015/09/SSE-Model-Guidance-onReporting-ESG.pdf

Sukhdev, P., Wittmer, H. and Miller, D. (2014) The Economics of Ecosystems and Biodiversity: Challenges and Responses, TEEB, http://www.teebweb.org/publication/teeb-challenges-responses/

Sustainable Stock Exchanges Initiative (2015) http://www.sseinitiative.org/

*Stern, N. (2006) Stern Review: The Economics of Climate Change, Department of Industry, UK Government

http://mudancasclimaticas.cptec.inpe.br/ rmclima/pdfs/destaques/sternreview_report_com plete.pdf

SustainAbility, Rate the Raters Project, 2013, http://www.sustainability.com/projects/ratethe-raters;

*TCFD (2017a) Final Report, Recommendations of the Task Force on Climate-Related Financial Disclosures, Task Force on Climate-Related Financial Disclosures, https://www.fsb-tcfd.org/wp-content/uploads/2017/06/FINAL-TCFD-Report-062817.pdf

*TCFD (2017b) Task Force on Climate-Related Financial Disclosures: Overview and Recommendations, https://www.fsb-tcfd.org/wp-content/uploads/2017/06/TCFDRecommendations-Overview-062717.pdf

The Climate Group (2015) http://www.theclimategroup.org/

*Ten Kate, A. (2011) Royal Dutch Shell and its Sustainability Troubles, Background report to the Erratum of Shell's Annual Report 2010, Friends of the Earth, Netherlands, http://www.foei.org/wp-content/uploads/2011/05/Shell-background-report.pdf

*TerraChoice (2010) The Six Sins of Greenwashing: A Study of Environmental Claims in North American Consumer Markets, Northbrook, Il: Underwriters Laboratories http://sinsofgreenwashing.com/index35c6.pdf

Trucost, http://www.trucost.com/what-we-do;

Trucost/TEEB (2013) Natural Capital at Risk: The Top 100 Externalities of Business, http://www.trucost.com/published-research/99/natural-capital-at-risk-the-top-100externalities-of-business 
UN Global Compact (2015) Guide to Corporate Sustainability, United Nations https://www.unglobalcompact.org/docs/publications/UN_Global_Compact_Guide_to_Cor porate_Sustainability.pdf

UNEP (2011) Towards a Green Economy: Pathways to Sustainable Development and Poverty Eradication - A Synthesis for Policy Makers, United Nations Environment Program, www.unep.org/greeneconomy

UN Global Compact (2010) Adapting for a Green Economy: Companies, Communities and Climate Change, A Caring for Climate Report for the UN Global Compact, United Nations https://www.unglobalcompact.org/;

UNEP, Fiduciary Duty in the 21 st Century, http://www.unepfi.org/fileadmin/documents/fiduciary_duty_21st_century.pdf

UN Global Compact (2014) Building the Post-2015 Business Engagement Architecture, United Nations https://www.unglobalcompact.org/docs/about the gc/Architecture.pdf

UN Global Compact (2015) Guide to Corporate Sustainability, United Nations https://www.unglobalcompact.org/docs/publications/UN_Global_Compact_Guide_to_Cor porate_Sustainability.pdf

United Nations (2015) The Millennium Development Goals Report, United Nations, http://www.un.org/millenniumgoals/2015_MDG_Report/pdf/MDG\%202015\%20rev\%20( $\underline{\text { July\%201).pdf }}$

UNFCCC, Copenhagen Accord, U.N. Doc. FCCC/CP/2009/L.7 (Dec. 18, 2009), http://unfccc.int/resource/docs/2009/cop15/eng/107.pdf;

UNFCC (2010) The Cancun Agreements, UN Climate Change Conference http://cancun.unfccc.int/cancun-agreements/significance-of-the-key-agreements-reachedat-cancun/

UNFCCC (2013) Warsaw agreement in 2013 discussed support for measures to address loss and damage. See http://unfccc.int/resource/docs/2013/cop19/eng/10a01.pdf

UNFCCC (2015) Adoption of the Paris Agreement, FCCC/CP/2015/L.9/Rev.1 (Dec. 12, 2015) http://unfccc.int/resource/docs/2015/cop21/eng/109.pdf

Vogel, D. (2005) The Market for Virtue: The Potential and Limits of Corporate Social Responsibility, Washington, DC: Brookings Institute

Walker, K., and Wan, F., (2012) The Harm of Symbolic Actions and Greenwashing: Corporate Actions and Communications on Environmental Performance and their Financial Implications, Journal of Business Ethics, 109, 227-242 
WBCSD, Vision 2050, WBCSD 2010, http://www.wbcsd.org/vision2050.aspx

WBCSD (2015) The CEO Guide to Climate Action 2015, WBCSD

http://www.wbcsd.org/Pages/EDocument/EDocumentDetails.aspx?ID=16483\&NoSearch

ContextKey=true

We Are Still In (2017) Open Letter to the International Community and Parties to the Paris Agreement, U.S. State, Local and Business Leaders

WFE (2017) The Role of Stock Exchanges in Fostering Economic Growth and Sustainable Development, World Federation of Exchanges and UNCTAD

Wright, C. and Nyberg, D. (2015) Climate Change, Capitalism and Corporations:

Processes of Creative Self-Destruction, Cambridge University Press 